\title{
Fishermen's perception of climate change - a study from Andhra Pradesh
}

\author{
MUKTHA MENON, SHUBHADEEP GHOSH, M. SATISH KUMAR, M. V. HANUMANTHA RAO, \\ V. UMA MAHESH AND P. U. ZACHARIA* \\ Visakhapatnam Regional Centre of ICAR-Central Marine Fisheries Research Institute, Visakhapatnam - 530003 , \\ Andhra Pradesh, India \\ *ICAR-Central Marine Fisheries Research Institute, Kochi - 682 018, Kerala, India \\ e-mail: muktha@cmfri.org.in
}

\begin{abstract}
Perceptions of fishermen on climate change were studied from two coastal districts of Andhra Pradesh during 2011. Fishermen were interviewed to know their perception on climate change over the last 20 years, impact of change in climatic parameters on their lives as well as on marine fisheries and on the adaptation measures required. All fishermen contacted believed that climate had changed in the last two decades. Wind was ranked as the parameter that had changed the most in the last two decades. Sea status was ranked as the most problematic to fishermen. Avenue for safe exit from villages and coastal protection structures in case of natural calamities were the highest scoring adaptation measures. Wind was found the most critical parameter affecting marine fishery and overfishing was identified as the biggest problem facing fisheries.
\end{abstract}

Keywords: Andhra Pradesh, Climate change, Fishermen, Perceptions

\section{Introduction}

The impact of climate change on fish is a widely researched field with a number of studies on how climate variability and on a long term basis, climate change impacts marine fish (Brander, 2010). Climate variability affects the spatial and temporal distribution, patterns of migration, diversity and abundance, reproduction and recruitment of economically important species (Jacobson and Maccall, 1993; Murawski, 1993; Finney et. al., 2000). The Intergovernmental Panel on Climate Change (IPCC) has projected that the global annual seawater temperature and sea level would rise by 0.8 to $2.5^{\circ} \mathrm{C}$ and 8 to $25 \mathrm{~cm}$, respectively by 2050 (IPCC, 2007). Increased incidence of extreme events such as storms and floods will affect the safety and efficiency of fishing operations and flow of rivers. This in turn will have severe impacts on fisheries as well as fishermen. Therefore, it is valid to analyse how fisheries react and adapt to existing climate fluctuations. Marine fishermen mainly reside in coastal areas and are vulnerable to climate on two fronts the ocean and the land. Impacts of climate variability in the ocean namely sea status, shift in current patterns and seasonal wind direction/speed impact their access to fishing grounds and ultimately access to fish. Coastal habitats are likely to be impacted through sea level rise and increased coastal erosion which in turn impacts the safety of fishermen dwellings. Frequent and intense extreme weather events such as cyclones, floods, hailstorms also impact fishermen directly. Thus fishermen as a group are one of the most vulnerable to the effects of increased climatic variability.
Marine capture fisheries have very important roles for food supply, food security and income generation in India. With a coastline of over $8,000 \mathrm{~km}$ and an Exclusive Economic Zone (EEZ) of over 2 million sq. km, marine fisheries play a vital role in the economy of the country. India is the third largest fish producer in the world with nearly 6 million fishermen, of which 2.4 million are full time, 1.45 million are part-time and the rest are occasional fishermen (CMFRI, 2010). Fisheries in India are also subjected to climate variability as in any other part of the world. In India, the following responses to climate change by different marine species are discernible: (i) changes in phytoplankton species composition; (ii) extension of distributional boundary and depth of occurrence of small pelagics and (iii) phenological changes (Vivekanandan, 2011). The surface waters of the Indian seas are warming by $0.04^{\circ} \mathrm{C}$ per decade and this has enabled the Indian oilsardine and Indian mackerel to extend their distributional ranges to northern latitudes (Vivekanandan et al., 2009a). The Indian mackerel, Rastrelliger kanagurta, are found to descend to deeper waters in the last two decades (CMFRI, 2008). There is a shift in the spawning season from warmer (April-September) to relatively cooler months (October-March) for threadfin breams (Vivekanandan and Rajagopalan, 2009). Coral reefs in India, when stressed by higher than normal sea temperature exhibit coral bleaching and death, resulting in reduction of the productivity of coral reef fisheries (Vivekanandan et al., 2009b). Sea level rise of $1.3 \mathrm{~mm}$ per year on average has been predicted in India (Parikh and Parikh, 2002). Sea level 
rise will have effects on the coastal profile and livelihoods of communities. Acidification of water will have effects on calciferous animals. Thus there have been reports of both positive and negative effects of climate change from the Indian seas. India is considered highly vulnerable to climate change because of the dependency of its economy and majority of population on climate-sensitive factors (agriculture, forests, tourism, animal husbandry and fisheries). Coastal fishermen being directly exposed to climate variability, are probably more inclined to believe in climate change than the normal population who do not perceive direct effect on their lives. Impact of climate change is expected to force the fishermen communities to make major social adaptation to overcome the adverse effects of climate change.

Despite the availability of scientific evidence regarding climate change (Vivekanandan, 2011), it is critical to obtain information on how the primary stakeholders of a fishery i.e. the fishermen perceive climate change. Before any adaptation measures can be designed, information is needed on what fishermen believe as the climatic feature that has most impact on their lives. For example, the factors that may be important from a fishery point of view need not be important with respect to their general well-being. Therefore, unless what fishermen perceive as important is not incorporated into the management programs or adaptation initiatives proposed by state or national agencies, they are bound to fail. Hence, this study was undertaken to understand what fishermen perceive as the most important climatic factors affecting both their lives and fisheries. The study was conducted in two coastal districts namely, Visakhapatnam and East Godavari in the state of Andhra Pradesh which lies on the eastern seaboard of India. This is one of the few studies of its kind in India, wherein the perception of marine fishermen to climate change of seas has been examined. The study area borders the Bay of Bengal which has been predicted to be one of the large marine ecosystems (BOBLME) to undergo substantial change in the years to come with respect to climate change. The bay is home to a million fishermen in the artisanal, motorised and mechanised sector fully or partially dependent on fisheries for livelihoods (CMFRI, 2010). Visakhapatnam and East Godavari districts have the largest proportion of fishermen families in the state. These two districts also have the largest proportion of mechanised trawlers as well as motorised and non-motorised crafts (CMFRI, 2010). Hence it was deemed appropriate to conduct the study in Visakhapatnam and East Godavari districts of Andhra Pradesh.

\section{Materials and methods}

There are approximately half a lakh active fishermen in Visakhapatnam and East Godavari districts (CMFRI, 2010). A survey of active fishermen was conducted in these two districts. Respondents were selected randomly assuming all members of the active fishermen population to have equal chances of being selected for the sample. A total of 301 respondents were surveyed during April - May 2011 from 12 fishing villages and 2 major fishing harbours of Visakhapatnam and East Godavari districts. Two fishing sectors, namely, motorised and mechanised were covered under the survey. Depending on favourable wind conditions, these fishermen may also use sails to reach the fishing grounds. Main fishing gears are gillnets, hooks and lines and ringseines. A total of 235 respondents were covered from the motorised sector and 66 from the mechanised sector.

Each respondent was given a structured interview schedule where the first question was whether they knew about climate change. If the answer was affirmative they were asked to rank parameters in six categories from 1 to $n$, where $n$ is the number of parameters, based on reverse order of importance (Table 1). Rank 1 would therefore imply a very important criterion and rank $n$ a criterion of least importance to the respondent. No parameter could be left unranked. The parameters for various categories were selected based on their importance to climate change and on preliminary investigation of climate change effect in the region. Fishermen were also asked questions regarding willingness to take weather-related insurance, method of accessing weather-related information, change in fishery output and prediction of weather and fish catch from oceanographic conditions. The ranking patterns within each category was analysed using rank cluster package in R (Jacques et al., 2014) based on the clustering algorithm of Jacques and Biernacki (2012). The algorithm would create

Table 1. Category and climatic parameters considered for ranking

\begin{tabular}{ll}
\hline Category & Parameter \\
\hline $\begin{array}{l}\text { Which parameter has changed the most during the last } \\
20 \text { years? }\end{array}$ & $\begin{array}{l}\text { Temperature, salinity, sea level rise, wind direction/speed, rainfall, } \\
\text { chlorophyll, others }\end{array}$ \\
$\begin{array}{l}\text { Most important climate related problem in the last } \\
\text { E years }\end{array}$ & $\begin{array}{l}\text { Erosion, cyclone, sea status, ground water salination, others } \\
\text { Adaptation measures to weather-related problems }\end{array}$ \\
Most important parameter affecting fishery & $\begin{array}{l}\text { Safe exit from fishing village, coastal protection structures, common } \\
\text { shelters, rehabilitation, others } \\
\text { Temperature, salinity, sea level rise, wind direction/speed, rainfall, } \\
\text { chlorophyll, others }\end{array}$ \\
Major problem faced by marine fisheries & $\begin{array}{l}\text { Overfishing, juvenile exploitation, habitat destruction, climate change, } \\
\text { others }\end{array}$ \\
\hline
\end{tabular}


cluster with each cluster having respondents who have similar ranking patterns. The results were further analysed with the variable ranked first in each cluster to form contingency tables based on various parameters of each respondent viz., age, experience, area of residence and fishing sector. Respondents were classified as young $(<35$ years old) and old ( $>35$ years old), less experienced ( $<20$ years fishing) and more experienced ( $>20$ years fishing), rural (residing in fishing villages) and urban (residing in cities) and non-mechanised (artisanal and motorised) and mechanised. If several clusters had the same variable ranked first, these clusters were combined before contingency tables were created. Results of the contingency tables depict percentage rather than actual numbers. The contingency tables were created to study the effect of age, experience, area of residence and fishing sector on the rankings.

\section{Results}

\section{Respondent profile}

Among the 301 respondents surveyed during the study, mean age of respondents was 36 years and mean fishing experience was 18.7 years. The classification of respondents based on fishing sector, age, experience and area of residence is given in Table 2. Though all classes were covered, the

Table 2. Classification of respondents

\begin{tabular}{lll}
\hline Category & $\%$ of respondents & No. of respondents \\
\hline $\begin{array}{ll}\text { Sector } \\
\quad \text { Motorised }\end{array}$ & 69.1 & 235 \\
$\quad$ Mechanised & 30.9 & 66 \\
Age & & \\
$\quad$ Old & 44.1 & 133 \\
$\quad$ Young & 54.9 & 168 \\
Fishing experience & & \\
$\quad$ Less experienced & 71.8 & 215 \\
$\quad$ More experienced & 28.2 & 86 \\
Area of residence & & \\
$\quad$ Rural & 81.7 & 246 \\
$\quad$ Urban & 18.3 & 55
\end{tabular}

sample size for each class varied with highest respondents from the motorised sector, young age group, less fishing experienced group and rural area (Table 2). The cluster analysis of ranking patterns for each category resulted in varying number of clusters per category. The modal ranking pattern and percentage of respondents who fell into each cluster is shown in Table 3.

\section{Climatic feature that changed the most}

All 301 fishermen interviewed believed that climate had changed during the last 20 years. The cluster analysis resulted in 5 clusters which were pooled into 3 groups based on the variable which ranked 1 i.e., Cluster 1 and 2 had the same variable ranked 1 and hence these two clusters were combined (Table 4). The 3 variables ranked first in the resulting 3 clusters were temperature, wind and rain. The highest percentage of respondents (age-based and area-based) categorised wind as the climatic feature that has changed the most in the last 20 years, followed by temperature and rain.

\section{Climatic feature that caused biggest problems to life}

The 6 clusters were pooled into 3 groups based on the variable ranked 1 (Table 5). The 3 variables were erosion, cyclone and sea state (condition of the sea surface). Based on age, the majority of respondents considered sea state as the most problematic climatic feature. But based on area of residence, rural respondents categorised sea state but urban residents categorised cyclone as the most problematic climatic feature.

\section{Best adaptation measure for climate variability}

Five clusters were pooled into 3 groups based on the variable ranked 1 (Table 6). The 3 variables were exit, protection and rehabilitation measures. Both by age and area of residence, the respondents categorised exit measures as the best adaptation strategy against climate variability. But the largest cluster (Table 3) indicated coastal protection as the most important option.

Table 3. Modal ranking pattern and percentage of respondents in each cluster

\begin{tabular}{lll}
\hline No. of clusters & Ranking pattern of biggest cluster (Rank 1 to Rank 5) & \% of respondents falling in the biggest cluster \\
\hline 5 & Wind, Rain, Temperature, Sea level rise, Others & 42.86 \\
3 & Wind, Rain, Temperature, Sea level rise, Others & 54.49 \\
6 & Sea state, Cyclone, Erosion, Groundwater, Others & 26.58 \\
4 & Overfishing, Juvenile fishing, Habitat degradation, Climate change, Others & 39.20 \\
5 & Coastal protection, Exit measures, Rehabilitation, Common shelters, Others & 30.56 \\
\hline
\end{tabular}

Table 4. Contingency table of climatic feature that has changed the most in the last 20 years (sample size in parenthesis)

\begin{tabular}{llllll}
\hline Pooled clusters & Variable ranked 1 & Young & Old & Rural & Urban \\
\hline $1 \& 2$ & Temperature & $30.36(51)$ & $26.32(35)$ & $30.28(66)$ & $24.10(20)$ \\
$3 \& 4$ & Wind & $44.64(75)$ & $49.62(66)$ & $45.41(99)$ & $50.60(42)$ \\
5 & Rain & $25.00(42)$ & $24.06(32)$ & $24.31(53)$ & $25.30(21)$ \\
\hline
\end{tabular}


Table 5. Contingency table of climatic feature that has caused biggest problems to life in the last 20 years (sample size in parenthesis)

\begin{tabular}{llllll}
\hline Pooled clusters & Variable ranked 1 & Young & Old & Rural & Urban \\
\hline 1 & Erosion & $11.31(19)$ & $12.78(17)$ & $13.41(32)$ & $5.45(4)$ \\
$2,3 \& 4$ & Cyclone & $37.50(63)$ & $32.33(43)$ & $31.30(63)$ & $52.73(43)$ \\
$5 \& 6$ & Sea state & $51.19(86)$ & $54.89(73)$ & $55.28(122)$ & $41.82(37)$ \\
\hline
\end{tabular}

Table 6. Contingency table of best adaptation measure for climate variability (sample size in parenthesis)

\begin{tabular}{llllll}
\hline Pooled clusters & Variable ranked 1 & Young & Old & Rural & Urban \\
\hline $1 \& 2$ & Exit & $39.88(67)$ & $41.35(55)$ & $42.22(95)$ & $35.53(27)$ \\
$3 \& 4$ & Protection & $38.10(64)$ & $32.33(43)$ & $36.44(82)$ & $32.89(25)$ \\
5 & Rehabilitation & $22.02(37)$ & $26.32(35)$ & $21.33(48)$ & $31.58(24)$ \\
\hline
\end{tabular}

\section{Climatic feature that affected fishery the most}

The 3 clusters were grouped into 2 groups based on the variable ranked 1 (Table 7). The 2 variables were wind and rain. By age and fishing experience, higher percentage of respondents categorised wind as the most important climatic feature that has affected the fishery. Rain and wind were catergorised as the most important feature affecting fishermen of the non-mechanised and mechanised sector respectively.

\section{Most serious problem facing the fishery}

The 3 clusters were grouped into 2 groups based on the variable ranked 1 (Table 8). The 2 variables were overfishing and habitat degradation. Majority of respondents by age, fishing experience and fishing sector categorised over-fishing as the most serious problem facing marine fisheries.

\section{Other issues}

Fishermen remarked on the change in quantity and type of fish caught presently (Table 9). All fishermen were willing to take insurance if financially supported by the national or state agencies. All fishermen followed popular media sources like television and radio to keep them updated regarding weather. This concurs with other studies (Anon., 2011) which also have indicated that majority of fishermen keep themselves updated regarding weather by following television or radio.

\section{Discussion}

\section{Climatic feature that has changed most}

Increased climatic variability over the past 20 years has been noted by all the fishermen surveyed, though the steady increase or decrease of a particular phenomenon over decadal time scales is not apparent. The most important climatic factor that was perceived by the fishermen to change the most was wind speed and direction followed by temperature and rain. Earlier studies have reported the same, wherein majority of the fishermen surveyed used wind for daily weather forecast in fishing operations (Bery, 2010;

Table 7. Contingency table of climatic feature that has affected the fishery the most (sample size in parenthesis)

\begin{tabular}{|c|c|c|c|c|c|c|c|}
\hline Pooled clusters & Variable ranked 1 & Young & Old & Less experienced & More experienced & Non-mechanised & Mechanised \\
\hline 1 & Wind & $53.57(90)$ & $55.64(74)$ & $53.70(116)$ & $56.47(48)$ & $49.52(103)$ & $65.59(61)$ \\
\hline $2 \& 3$ & Rain & $46.43(78)$ & $44.36(59)$ & $46.30(100)$ & $43.53(37)$ & $50.48(105)$ & $34.41(32)$ \\
\hline
\end{tabular}

Table 8. Contingency table of most serious problem facing the fishery (sample size in parenthesis)

\begin{tabular}{llllllll}
\hline Pooled clusters & Variable ranked 1 & Young & Old & Less experienced & More experienced & Non-mechanised & Mechanised \\
\hline $1 \& 2$ & Overfishing & $63.10(106)$ & $64.66(86)$ & $63.89(138)$ & $63.53(54)$ & $59.13(123)$ & $74.19(69)$ \\
$3 \& 4$ & Habitat degradation & $36.90(62)$ & $35.34(47)$ & $36.11(78)$ & $36.47(31)$ & $40.87(85)$ & $25.81(24)$ \\
\hline
\end{tabular}

Table 9. Important changes in marine fisheries of Andhra Pradesh as expressed by respondents

\begin{tabular}{lll}
\hline Feature that has changed & $\%$ of respondents & No. of respondents \\
\hline Fall in catch rate & 35.43 & 107 \\
Reduction in quantity & 27.56 & 83 \\
Reduction in diversity of fish & 22.05 & 66 \\
Reduction in value fish & 5.91 & 18 \\
Reduction in size of fish & 3.15 & 9 \\
Increase in pelagic fish catch & 3.15 & 9 \\
Increase in quantity & 2.76 & 8 \\
\hline
\end{tabular}


Salagrama, 2012). Wind direction and intensity off Andhra Pradesh has experienced wide fluctuations during 1960 to 2014 (Fig. 1 and 2). Increased uncertainty of wind direction and intensity is the most critical change impacting fisheries (Salagrama, 2012), with tremendous implications on pelagic fish shoals. The fluctuating wind velocities would impact the currents, upwelling processes, navigation and fishing effort. Studies have also shown the importance of wind variability on the formation of sea level anomalies which in turn affects the freshwater discharge from rivers into the sea leading to increased chances of flooding and disease occurrence among coastal populations (Han and Webster, 2002). The increasing levels of carbon-di-oxide and other 'greenhouse' gases in the atmosphere are resulting in an increase in seawater temperature (Fig. 3) and this has a number of implications on the fish and the fishermen. Increasing seawater temperature

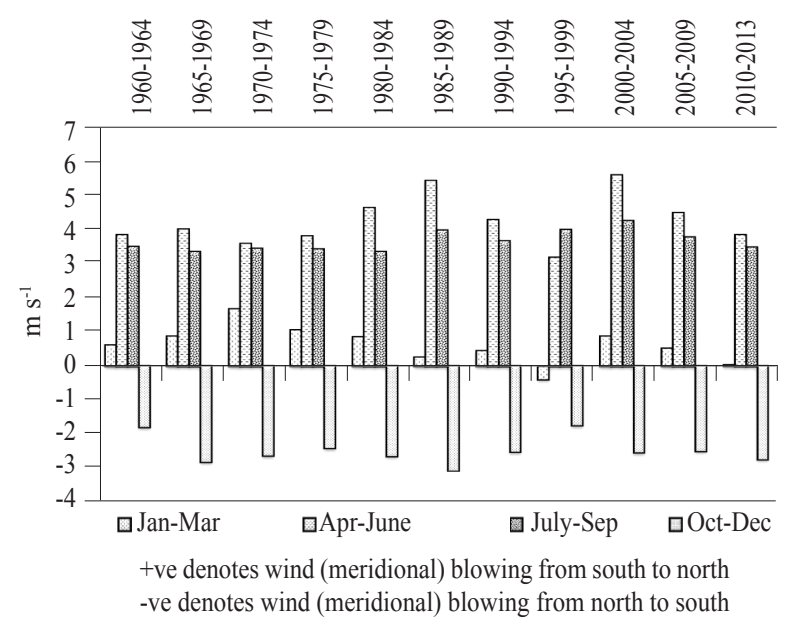

Fig. 1. Wind (meridional) direction and speed in different quarters off Andhra Pradesh during 1960 to 2014 (Source Data: International Comprehensive Ocean-Atmosphere Data Set Release 2.5) will have negative impacts on the physiology of fish resulting in changes in distributions, recruitment and abundance (Perry et al., 2005; Nye et al., 2009; Brander, 2010; Last et al., 2011). These changes are more pronounced in species with short life span and rapid turnover of generations, such as plankton and small pelagic fishes (Vivekanandan, 2011). Precipitation over the years has increased off Andhra Pradesh in the last three decades (Fig. 4). Increased precipitation with consequent flooding has impacts on fishermen lives. Precipitation timing and intensity affect spawning of most marine fishes and also leads to changes in marine resource availability.

\section{Climatic feature that caused biggest problems to life}

Sea status was ranked as the most problematic climatic feature by all ages of respondents. However, urban respondents preferred cyclone to sea state as the biggest problem. Urban respondents, by virtue of staying at distances from sea do not perceive sea state to be a major challenge, unlike rural respondents who stay in proximity to the shoreline and in all

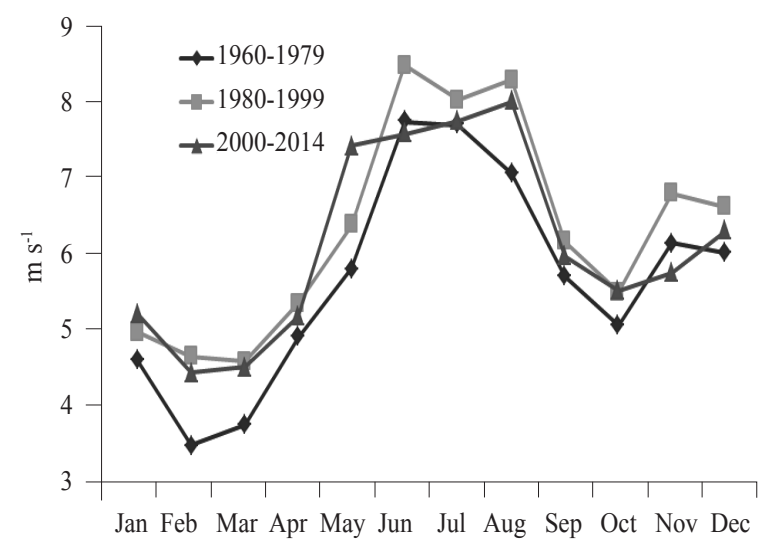

Fig. 2. Wind (meridional) speed in different months off Andhra Pradesh during 1960 to 2014 (Source Data: International Comprehensive Ocean Atmosphere Data Set Release 2.5)

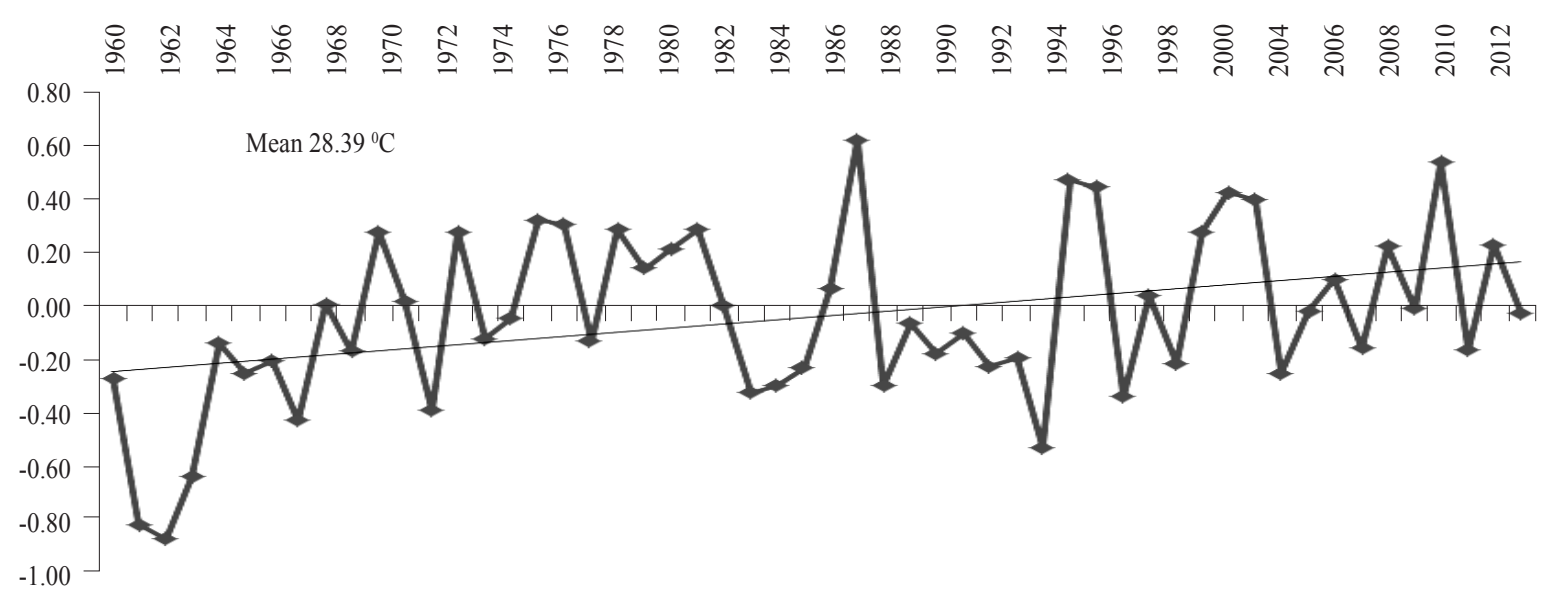

Fig. 3. Sea surface temperature anomaly off Andhra Pradesh during 1960-2013 (Source Data: International Comprehensive Ocean Atmosphere Data Set Release 2.5) 


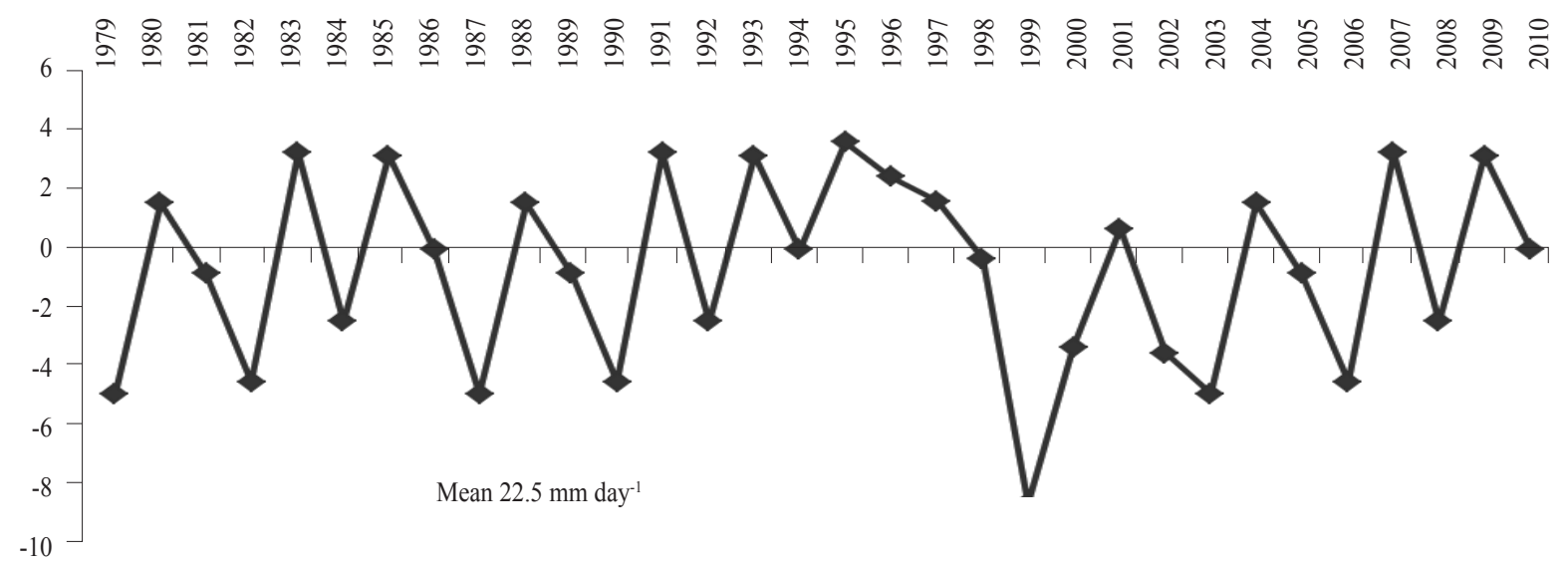

Fig. 4. Precipitation anomaly off Andhra Pradesh during 1979 - 2010 (Source Data: NCEP Climate Forecast System Reanalysis)

probability are more likely to be influenced by changes in sea state. Urban respondents foresee cyclones to be damaging because cyclones can potentially destroy vast areas. Sea level off Andhra Pradesh has increased by more than half a meter in the last three decades (Fig. 5). This will lead to elevated tidal inundation, increased flood frequency, accelerated erosion, rising water tables, increased saltwater intrusion, and a suite of other ecological changes (Church et al., 2001). These biophysical changes will cause various socio-economic impacts to the fishermen community including loss of land, infrastructure and coastal resources (Klein and Nicholls, 1999). Loss of fishing days, loss of crafts and gears as well as non-availability of resources are associated with turbulent sea state. Rougher seas also increase their risk factors. Cyclones are common along Andhra Pradesh coast and an increase in incidence is being reported (Fig. 6). Approximately 44\% of the state is vulnerable to cyclones and natural disasters (Anon., 2011). Land-based weather stations monitor the edges of the bay, but they cannot see much when the storm is brewing several hundred miles away from the coastline. Moreover, the small dimensions of the bay ensure that storms do not have much time to develop and circulate. Hence, when tropical cyclones form, flooding waves and storm surges can quickly reach the narrow basin's shores. Most fishermen live within $500 \mathrm{~m}$ of the shore and hence are vulnerable to coastal erosion, which is a direct threat to their dwellings and crafts. $\mathrm{H}$ ence they are concerned regarding increasing erosion, as it has a direct effect on their lives.

\section{Best adaptation measure for climate variability}

Coastal protection structures and safe exit from fishing villages in the event of a weather hazard were perceived to be the best adaptation strategies by the fishermen. Fishermen wanted more coastal protection structures to be erected. Rehabilitation programs also found preference among the fishermen. Interestingly, common shelters were not preferred, even though the state government has erected a large number of cyclone shelters in fishing villages across the state (Anon., 2011). However in Bangladesh, such shelters have helped to reduce mortality from cyclones (Adger et al., 2003). Thus the state agencies could give emphasis to development of infrastructure for safe exit from fishing villages and coastal protection structures.

\section{Climatic feature that affected fishery the most}

Wind direction and speed followed by rainfall were the two most important parameters affecting the fishery. In Andhra Pradesh, there is change in the intensity and

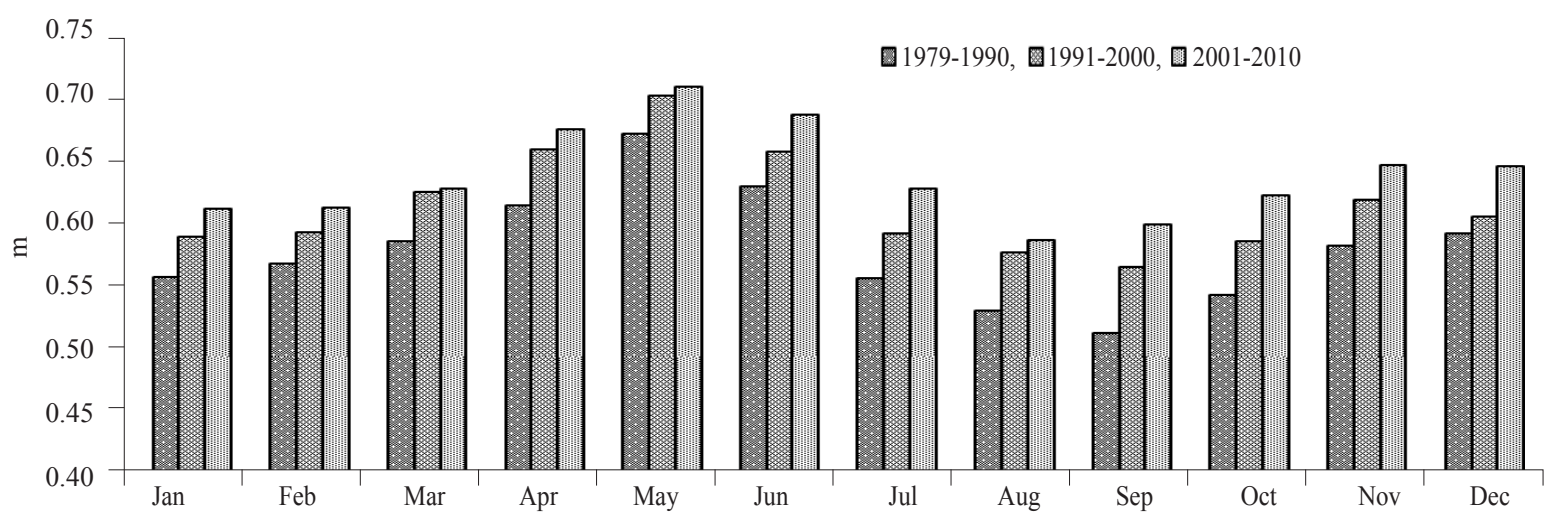

Fig. 5. Sea level off Andhra Pradesh during 1979 - 2010 (Source Data: NCEP Climate Forecast System Reanalysis) 


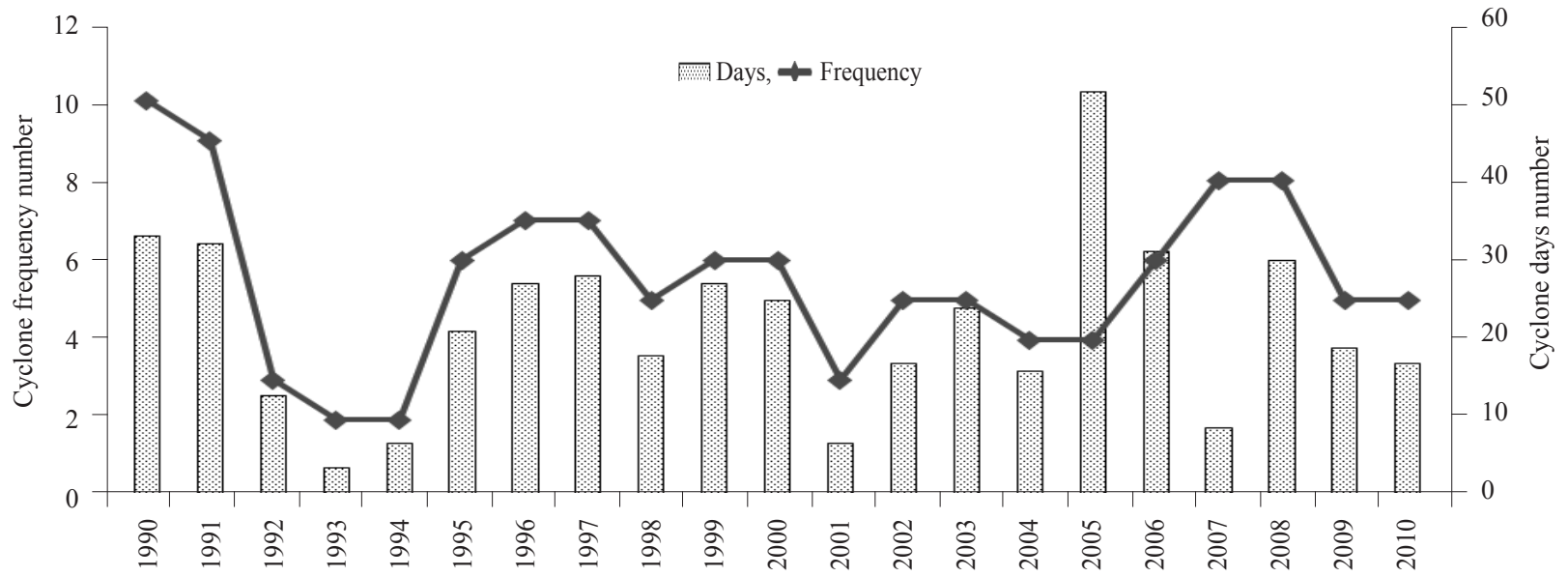

Fig. 6. Occurrence of cyclones in Bay of Bengal during 1990 to 2010 (Source Data: International Best Track Archive for Climate Stewardship)

duration of the winds during monsoon and winter months (Figs. 1 and 2), affecting the arrival of small and large pelagic shoals (Salagrama, 2012). Wind intensity and direction have tremendous impacts on resource distribution, reproduction and growth (Roessig et al., 2004; Harley et al., 2006). Unlike the mechanised sector which recognised wind to impact fishery the most, fishermen of motorised sector were of the opinion that rainfall maximally affected the fishery. Changes in rainfall affect the reproduction of fishes as well as access of the fishermen to fishing grounds. Though much has been reported on the effect of sea surface temperature (SST) to the fishery of the east coast of India (Vivekanandan, 2011), fishermen opined it to be not that important impacting the fishery. However, they stated that an increase in surface water temperature has forced the pelagic species to descend from surface to lower layers of water and as a consequence, the depth of operation of surface gillnets which was four fathoms in the 1980s, has now increased to nine fathoms.

\section{Most serious problem facing the fishery}

Overfishing emerged as the most important issue to plague the fishery indicating that fishermen have recognised the fact that overfishing of resources is taking place. Overfishing has long been recognised by the scientific community as detrimental to the fisheries sector. Validation of this by the fishermen gives hope that they can be educated regarding management of resources which are overfished. Habitat destruction has been seen critically by fishermen. The Bay of Bengal is bordered by mangroves which were being earlier degraded for commercial activities. Government of India has now brought in the Coastal Regulation Zone rules, which ban any activities that degrade mangroves. The problems of juvenile exploitation and pollution were also flagged by a few. Presently the marine fisheries scenario is such that any fish can be sold in the harbour, hence fishermen have no qualms about retaining under-sized fish and hence deterrents need to be put in place to avoid their capture and retention. According to some, dedicated effort for reducing coastal industrial pollution is required as industries dump their wastes into the sea.

\section{Other issues}

Majority of fishermen believed in reduction of catch and catch rate, which is not exactly the reality. The marine fish landings of Andhra Pradesh has increased from about a lakh $\mathrm{t}$ in 1981 to 3 lakh $\mathrm{t}$ in 2012 (Fig. 7). The catch rate of trawlers, though have decreased initially has been steady over the last decade (Fig. 8). There has been a quantum jump in the catch rates of gillnets during 1993-1998 after which it has been steady with inter-annual variations (Fig. 8). Increase in fishing effort and catch rate for Andhra Pradesh was reported for small trawlers from 1994 to 2003 as well as for larger sona trawlers from 1997 to 2003 (Rajkumar et al., 2005). Similarly an increase in fish landings and catch rates for multiday trawlers and gillnetters operating along the state was also reported during 2000-2010 (Maheswarudu et al., 2013). This paradox in fishermen's belief of lower catches and research indicating higher landings may probably be a result of the increasing competitiveness in marine fisheries. The number of active fishermen has increased from 138,614 in 2005 to 150,868 in 2010 in the state (CMFRI, 2005; CMFRI, 2010) resulting in more fishermen in the fishery and more competition for resources. Thus even though fish landings are increasing, the per-capita share for each fisherman might not be increasing. A small percentage of fishermen have reported increasing catches especially for that of pelagic resources. Increase in landings of pelagic fishes namely, tuna, Indian mackerel, seerfish and carangids has been reported for the state during 2000-2010 (Maheswarudu et al., 2013). Increased contribution by pelagic fishes to total trawl landings from $25 \%$ in 1990 s to $35 \%$ in 2000 has also been reported (Rajkumar et al., 2005).This is in concurrence to the views of the 


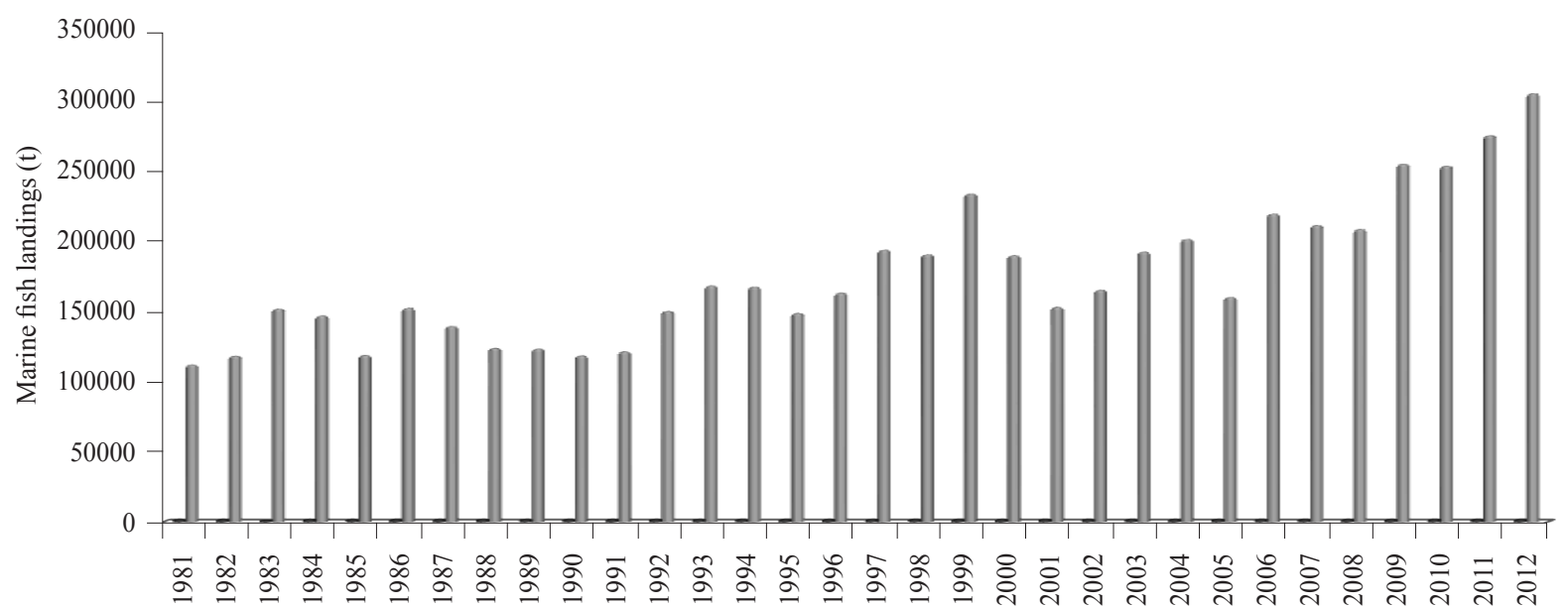

Fig. 7. Marine fish landings of Andhra Pradesh during 1981 - 2012

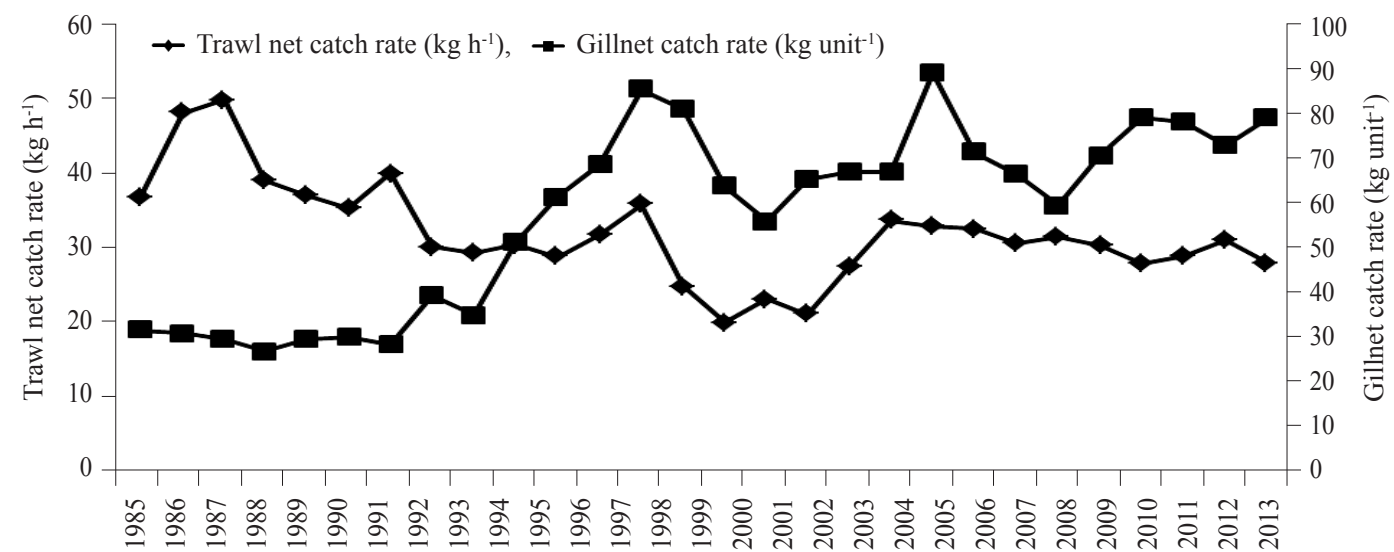

Fig. 8. Trends in catch rates of trawlers and gillnetters along Andhra Pradesh during 1985 to 2013

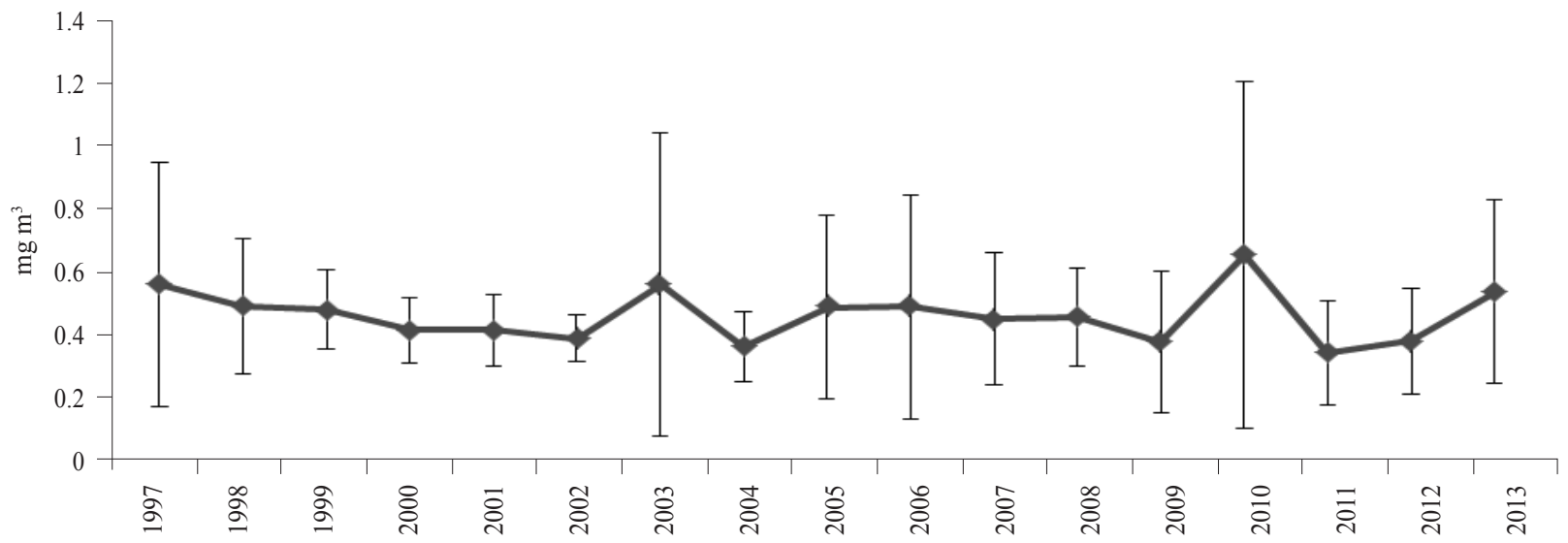

Annual chlorophyll $a$ content in waters off Andhra Pradesh during 1997 to 2013 (Source: Sea-viewing Wide Field-of-View Sensor \& Moderate Resolution Imaging Spectro Radiometer Aqua)

fishermen that pelagic species have descended to the lower layers from the surface because of increase in surface water temperature. Some fishermen observed that sizes of major fish species have reduced. This observation is also supported by research. On comparison of mean lengths of major fish and shellfish resources landed along the state during 2000-2006 and 2006-2010 (Maheswarudu et al., 2013), a decrease in mean sizes was seen for most major species. 
Mean lengths reduced by $9.6 \%$ for Indian mackerel, $23.6 \%$ for ribbonfishes, $8.5 \%$ for threadfin breams, $12.8 \%$ for goatfishes, $2.99 \%$ for lizardfishes, $45 \%$ for Metapenaeus monoceros and $42 \%$ for Metapenaeus dobsoni.

For effective fisheries management in a dynamic environment, fisheries managers not only require the knowledge of climate change but also need to understand the fishermen's responses to climate variability (Smit et al., 2000). Thus it is of utmost importance to understand whether fishermen have perceived and responded to climate variability. Wind emerged as the most critical climatic parameter considered by fishermen. Sea status has caused maximum issues which are set to increase with further climatic variability in the region. Most fishermen asked for avenues that would ensure safe exit from their fishing villages in the case of natural calamities and construction of coastal protection structures. Fishermen felt that wind was the most important factor influencing the fishery. Overexploitation was also recognised as a major problem. The perspective of the fishermen would impact their interaction with other interest groups and consequently the institutions that manage the resource. Their perception would also impact how they respond to any sensitisation and/or adaptation programs brought forth by government agencies thereby directly influencing the end result of such programs.

\section{Acknowledgements}

The authors are grateful to the Director, ICAR-Central Marine Fisheries Research Institute, Kochi for support and encouragement and for the facilities provided for the study. This study was carried out under the National Initiative on Climate Resilient Agriculture (NICRA) project funded by the Government of India.

\section{References}

Adger, W. N., Huq, S., Brown, K., Conway, D. and Hulme, M. 2003. Adaptation to climate change in the developing world. Progress in Development Studies, 3(3): 179-195.

Anon. 2011. State action plan on climate change for Andhra Pradesh - Draft report. Environment Protection Training and Research Institute, Hyderabad. Ministry of Environment and Forests, Government of India, New Delhi.

Bery, S. 2010. Impact assessment and economic benefits of weather and marine services. National Council of Applied Economic Research (NCAER), New Delhi, India, 128 pp.

Brander, K. 2010. Impacts of climate change on fisheries. J. Mar. Syst., 79: 389-402.

Church, J. A., Gregory, J. M., Huybrechts, P., Kuhn, M., Lambeck, K., Nhuan, M. T., Qin, D. and Woodworth, P. L. 2001. Changes in sea level. In: Houghton, J. T, Ding, Y., Griggs, D. J., Noguer, M., Van der Linden, P. J., Dai, X, Maskell, K. and Johnson, C. A. (Eds.), Climate 2001: The scientific basis. Contribution of Working Group 1 to the Third Assessment Report of the Intergovernmental Panel on Climate Change. Cambridge University Press, Cambridge, UK and New York, USA, p. 639-694.

CMFRI 2005. Marine fisheries census 2005. Central Marine Fisheries Research Institute, Kochi, India.

CMFRI 2008. Research highlights 2007-2008. Central Marine Fisheries Research Institute, Kochi, India.

CMFRI 2010. Marine fisheries census 2010. Central Marine Fisheries Research Institute, Kochi, India.

Finney, B. P., Gregory-Eaves, I., Sweetman, J., Dougas, M. S. V. and Smol, J. P. 2000. Impacts of climatic change and fishing on pacific salmon abundance over the past 300 years. Science, 290(5492): 795-799.

Han, W. and Webster,. P. J. 2002. Forcing mechanisms of sea-level inter annual variability in the Bay of Bengal. J. Phys. Oceanogr., 32: 216-239.

Harley, C. D. G., Hughes, A. R., Hultgren, K., Mine,r B. G., Sorte, C. J. B., Thornber, C. S., Rodriguez, L. F., Tomanek, L. and Williams, S. L. 2006. The impacts of climate change in coastal marine systems. Ecol. Lett., 9: 228-241.

IPCC 2007. Climate change 2007. The physical science basis. Contribution of Working Group I to the Fourth Assessment Report of the IPCC. Cambridge University Press, UK.

Jacobson, L. D. and Maccall, A. D. 1995. Stock-recruitment models for pacific sardine (Sardinops sagax). Can. J. Fish. Aquat. Sci., 52(3): 566-77.

Jacques, J. and Biernaki, C. 2012. Model-based clustering for multivariate partial ranking data. Technical Report 8113, Inria Research Report, University of Lille, France.

Jacques, J., Quentin, G. and Biernacki, C. 2014. Rankcluster: An $\mathrm{R}$ Package for clustering multivariate partial rankings. The $R$. Journal, 6(1): 101-110.

Klein, R. J. T. and Nicholls, R. J. 1999. Assessment of coastal vulnerability to climate change. Ambio., 28(2): 182-187.

Last, P. R., White, W. T., Gledhill, D. C., Hobday, A. J., Brown, R., Edgar, G. J. and Pecl, G. T. 2011. Longterm shifts in abundance and distribution of a temperate fish fauna: a response to climate change and fishing practices. Global Ecol. Biogeogr., 20(1): 58-72.

Maheswarudu, G., Rao, G., Syda, Rohit Prathibha, Laxmilatha, P, Ghosh Shubhadeep and Muktha, M. 2013. ). Marine fisheries of Andhra Pradesh: a decadal analysis. Indian J. Fish., 60(3): 27-33.

Murawski, S. A. 1993. Climate change and marine fish distributions: forecasting from historical analogy. T. Am. Fish. Soc., 122(5): 647-58.

Nye, J. A., Link, J. S., Hare, J. A, and Overholtz, W. J. 2009. Changing spatial distribution of fish stocks in relation to climate and population size on the North-east United States continental shelf. Mar. Ecol. Prog. Ser., 393: 111-29. 
Parikh, J. K. and Parikh, K. 2002. Climate change: India's perceptions, positions, policies and possibilities. OECD, Climate Change and Development, Indira Gandhi Institute of Development Research, India.

Perry, A. L., Low, P. J., Ellis, J. R. and Reynolds, J. D. 2005. Climate change and distribution shifts in marine fishes. Science., 308: 1912 - 1915.

Rajkumar, U., Maheswarudu, G,., Nasser. A. K. V., Rao K. Narayana., Kingsly, H. Jose., Varma, J. B. and Rao M. Prasada. 2005. Trawl fisheries off Visakhapatnam. In: Proceedings of the Seminar on Sustainable fisheries development: Focus on Andhra Pradesh, Society of Fisheries Technologysts (India), Kochi, India, p. 35-49

Roessig, J. M., Woodley, C. M., Cech, J. J. and Hansen L. J. 2004. Effects of global climate change on marine and estuarine fishes and fisheries. Rev. Fish Biol. Fisher., 14: 251-275.

Salagrama, V. 2012. Climate change and fisheries: perspectives from small-scale fishing communities in India on measures to protect life and livelihood. International Collective in Support of Fishworkers, Chennai, India and Heinrich BollStiftungIndia, New Delhi, India.
Smit, B., Burton, I., Klein, R. J. T. and Wandel, J. 2000. An anatomy of adaptation to climate change and variability. Climatic Change, 45: 223-251.

Vivekanandan, E., Rajagopalan, M. and Pillai, N. G. K. 2009. Recent trends in sea surface temperature and its impact on oil sardine. In: Aggarwal, P. K. (Ed.), Impact, adaptation and vulnerability of Indian agriculture to climate change. Indian Council of Agricultural Research, New Delhi, p. 89-92.

Vivekanandan, E. and Rajagopalan, M. 2009. Impact of rise in seawater temperature on the spawning of threadfin breams, In: Aggarwal, P. K. (Ed.), Impact, adaptation and vulnerability of Indian agriculture to climate change. Indian Council of Agricultural Research, New Delhi, p. 93-96.

Vivekanandan, E., Hussain Ali M. and Rajagopalan, M. 2009. Vulnerability of corals to seawater warming, In: Aggarwal, P. K. (Ed.), Impact, adaptation and vulnerability of Indian agriculture to climate change. Indian Council of Agricultural Research, New Delhi, p. 97-100.

Vivekanandan, E. 2011. Climate change and Indian marine fisheries. Marine fisheries policy brief 3, Central Marine Fisheries Research Institute, Kochi. 